\section{原 著}

論文受付

2007年11月21日

論文受理

2008年10月6日

Code Nos. $\begin{array}{r}620 \\ 873\end{array}$

\section{血管撮影時における術者手指被曝線量低減方法に関する検討}

\author{
坂本 肇・池川博昭・小林 寛・木内㻟也・ \\ 佐野芳知・深澤瑞也 ${ }^{1)} \cdot$ 荒木 力 \\ 山梨大学医学部附属病院放射線部 \\ 1 ) 山梨大学大学院医学工学総合教育部泌尿器科
}

\section{緒 言}

血管撮影領域において, interventional radiology (以下, IVR)の普及に伴い診断から治療へと移行す る件数は増加傾向にある.IVRは手技の高度化や内 容の複雑化，適応範囲の拡大により透視時間が長く 撮影回数も多くなり, 患者や従事者の被曝線量が増 加する傾向にあり，放射線障害を起こした事例も報 告されている ${ }^{1 \sim 5)}$.

医療のなかでもIVR術者は, International Commission on Radiological Protection (以下, ICRP) publication 73の「医学における放射線の防護と安全」におい て被曝管理が特に重要であるとされている6)。また， 最近のIVRにおいて術者は高い専門性が要求される
ようになり，ある程度限定された術者が数多くの症例 を行う傾向になっているため, 特定の術者の被曝線 量が増加し, 被曝線量低減のための対策が必要に なっている。術者の被曝線量は医療法施行規則(第30 条の27)において年間の線量限度が定められているた め線量把握が必須となっており，血管撮影領域での 術者の実効線量や体幹部の線量は防護衣や防護具の 効果により低い值となっていたが，末端部で放射線 防護の難しい手指の線量は他の部位に比較し高い值 となっている7〜13).

そこで血管撮影領域での術者被曝部位のなかにお ける手指部線量を中心に評価し, 術者が安全に手技 を施行するための被曝線量低減方法について検討し

\title{
A Study of Operator's Hand and Finger Exposure Dose Reduction During Angiographic Procedures
}

\author{
Hajime Sakamoto, Hiroaki Ikegawa, Hiroshi Kobayashi, Takuya Kiuchi, Yoshitomo Sano, \\ Mizuya Fukasawa, ${ }^{1)}$ and Tsutomu Araki \\ Department of Radiology, University of Yamanashi Hospital \\ 1 ) Department of Urology, Interdisciplinary Graduate School of Medicine and Engineering, \\ University of Yamanashi Medicine \\ Received Nov. 21, 2007; Revision accepted oct. 6, 2008; Code Nos. 620, 873
}

\section{Summary}

The number of examinations using interventional radiology (IVR) has increased recently. Because of the more advanced and more complex procedures for IVR, longer treatment time is required. Therefore, it is important to determine exposure doses. We measured operator exposure dose during IVR using a thermoluminescence dosimeter. The results revealed the dose equivalent to the operator's hands and fingers to be higher than that of other parts, although the effective dose for the operator was low. Moreover, we looked into the factors that affected exposure dose to the operator's fingers, and examined ways to reduce the dose. In regard to the exposed dose to the operator's fingers, dose reduction was possible as a result of a geometric arrangement of the fluoroscopic unit, the radiation field size, using a radiation protective device and deliberation to exposure dose reduction of the operator. It is possible to carry out IVR more safely using the method of exposure dose reduction to the operator's fingers.

Key words: operator dose, dose to hands and fingers, dose reduction, interventional radiology, angiography

別刷資料請求先：テ409-3898 山梨県中央市下河東1110

山梨大学医学部附属病院放射線部 坂本 肇 宛 
たので報告する。

\section{1. 方 法}

\section{1-1 使用機器}

血管撮影装置 (1)：BICOR T.O.P. (シーメンス旭メディ テック株式会社製)

血管撮影装置 (2)：DFP2000A（東芝メディカルシステ ムズ株式会社製)

X線発生装置：POLYDOROS IS-C (シーメンス旭メ デイテック株式会社製)

：KXO-80C (東芝メデイカルシステムズ

株式会社製)

電離箱線量計：UNIDOS M10001(PTW社製)

プローブ : Model 30006(0.6cc) (PTW社製)

電離箱式サーベイメータ：ICS-311(ALOKA株式会社

製)

TLD：UD-170A（松下電器株式会社製）

TLDリーダー：UD-512(松下電器株式会社製)

面積線量計：DIAMENTOR K2(PTW社製)

X線防護手袋：X線ガードグローブ(インターナショナ ルバイオメデイカル社製)

天井懸垂型防護板 : PT6274Type (Pb 0.5mm) (MAVIG 社製)

被写体：人体ファントムBP 10 (京都科学社製)

: アクリル板

なお, thermoluminescence dosimeter (以下, TLD) は実効エネルギー35.7keVで，リファレンス線量計と した電離箱線量計により空中において同時照射を行 い校正した。また，使用したTLDのエネルギー特性は 20〜60keVの範囲で35.7 keVに対し士4\%程度である。

\section{1-2 術者の手指線量}

血管撮影時の術者の各部位における被曝線量の現 状を把握するため, 当施設における術者皮膚の $70 \mu \mathrm{m}$ 線量当量(以下，H70 $\mathrm{mm}$ )をTLDによって測定した。

TLDの測定值(照射線量)から $\mathrm{H} 70 \mu \mathrm{m} \sim の$ 変換につ いては，光子に対する放射線荷重係数の值が 1 であ り, 蔵器吸収線量は臓器等価線量に等しいことか ら，皮膚吸収線量を求め皮膚線量当量とした ${ }^{14,15)}$. なお，皮膚面でのX線エネルギーの同定が困難である ため, 照射線量一吸収線量変換係数は $36.0(\mathrm{~Gy} \cdot \mathrm{kg} / \mathrm{C})$ を用いた16)

\section{1-2-1 術者の皮膚線量}

血管撮影領域における術者の被曝線量を評価し た. 対象症例は頭部領域(20例), 心臓領域(90例), 腹部領域 (50例), 四肢領域 (60例)での診断検査およ びIVRの計220例である。なお, 頭部, 腹部, 四肢領 域は装置(2), 心蔵領域は装置(1)を使用した.
測定部位は第 1 術者の頸部(ネックガード装着時は その外側), 両肩, 両手背, 両指(手背側) の $\mathrm{H} 70 \mu \mathrm{m}$ である。測定においては，TLDを各部位へ直接貼り 付けたが，手背と指へは滅菌されたシートと手袋を 用いて清潔を維持し，それぞれ 1 症例ごとの各部位 での術者皮膚のH70 $\mathrm{mm}$ を比較した。なお，左右の手 背は第 2 指側および第 5 指側, 指は第 2 指および第 5 指の 2 力所を測定し, そのうちの高い線量を手部と 指部の線量とした。

\section{1-2-2 検査領域別の術者手指線量}

血管撮影領域での検査領域別の術者における手指 線量を評価するため，1-2-1において測定した症例の 各領域別での手指部の $\mathrm{H} 70 \mu \mathrm{m}$ を比較した。検査領域 を頭部, 心臓, 腹部, 四肢領域に区別し, 1 症例ごと のH70 $\mu \mathrm{m}$ を比較した。なお，四肢領域は前腕部の透 析シャント治療のvascular access interventional therapy（以下, VAIVT) 症例である。

\section{1-2-3 穿刺部位別の術者手指線量}

血管撮影領域において同一手技を行う場合での穿 刺部位の違いによる術者手指線量の評価を行うた め, 1-2-1 での心臓領域における右大腿部穿刺症例 (50例) と右橈骨部穿刺症例(30例)での左右の手部と 指部の 1 症例ごとの $170 \mu \mathrm{m}$ を比較した。 また, 各症 例時の面積線量值も同時に測定した.

\section{1-3X線装置に関連する術者手指被曝への影響}

$\mathrm{X}$ 線装置に関連する術者手指部の被曝線量に影響 を及ぼす因子のうち，装置の幾何学的配置および照 射野による影響について検討した。なお，実験には 装置(2)を使用した。

\section{1-3-1 幾何学的配置による影響}

術者手指部の被曝線量が多くなる原因は，照射野 内や近傍における手技による。血管撮影領域におい て用いられるアンダーテーブル方式にて手技を行う 場合，検出器と被写体の間に手技スペースを設けな ければならない症例がある。Fig. 1(a)に示すようにス ペースを確保するためには，テーブルを下げ焦点一 被写体表面間距離(focus-to-surface distance：以下, FSD)を短くする方法とimage intensifier (以下, I.I.) を上げ焦点－I.I.間距離(focus-to-image intensifier distance : 以下, FID)を長くする 2 通りの方法があ る。そこで，被写体として人体ファントムを用い, FID $100 \mathrm{~cm}$ 一定としFSDを80〜 55cmへと下げスペース を確保する方法とFSD65cm一定としFIDを85〜 105cm へと上げスペースを確保する方法について，照射野 端より側方 $20 \mathrm{~cm}$ 位置での空間線量 $(1 \mathrm{~cm}$ 線量当量)を 電離箱式サーベイメータで測定した。電離箱式サー ベイメータの配置は測定面をI.I.側に向け測定し，同 


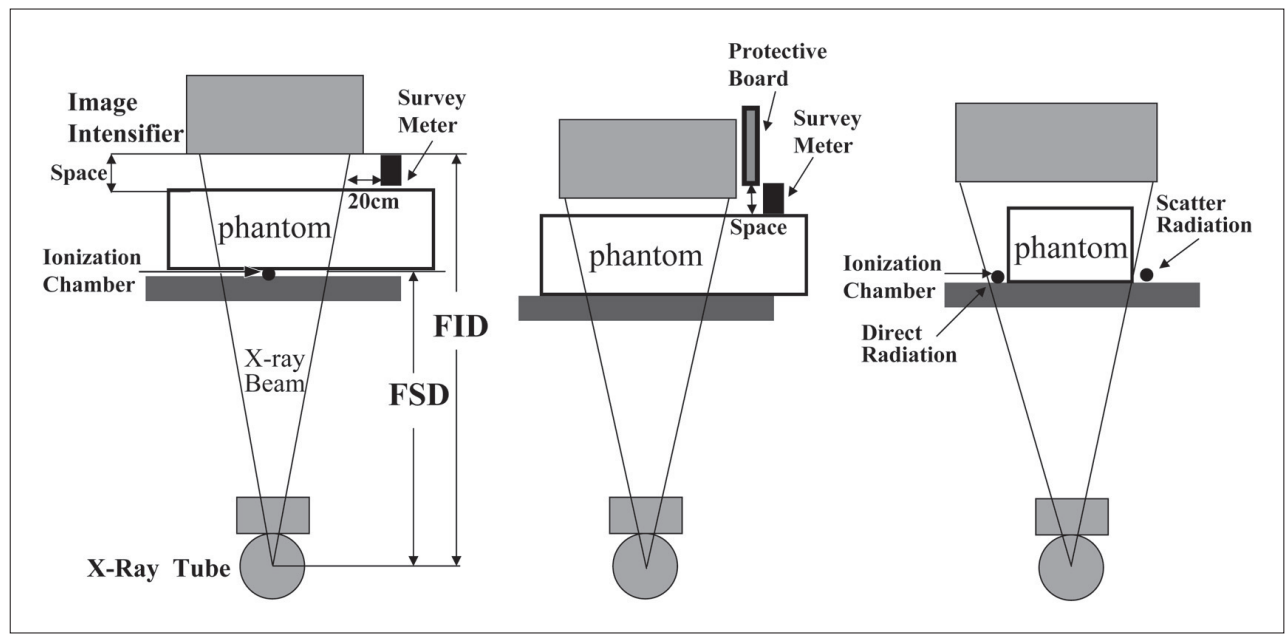

Fig. 1 Geometric arrangement for the fundamental experiment.

(a) Focus-to-surface distance (FSD) and focus-to-image intensifier distance (FID) were changed to secure the space. Then space dose and phantom surface dose were measured.

(b) Height of the protective board from the phantom was changed. Then space dose was measured.

(c) Measuring positions of direct and scatter radiation are illustrated.

時に被写体への入射表面線量を電離箱線量計におい て測定した。なお，透視による 1 分間当たりの線量を 測定し，透視条件は装置の自動露出機構を作動させ 管電圧 $60 \sim 67 \mathrm{kV}$ ，管電流 $50 \mathrm{~mA}$ ，パルス幅 $2 \mathrm{msec}$, パルスレート $15 \mathrm{p} / \mathrm{s} の$ 範囲で照射を行った。

\section{1-3-2＼cjkstart照射野による影響}

術者の手指線量は, 1-2-2 での検査部位により線量 に差が生じ, 線量の高かった四肢領域では照射野近 傍の手技となるため照射野による影響を受ける。 そこ で，照射野の形状，ハレーション防止に用いる濃度 補償用フィルタ（材質：含鉛ゴム)の使用による照射 野内の線量分布を比較した。

測定は前腕部ファントムを用い，照射野内外に $1 \mathrm{~cm}$ 間隔にてTLDを配置し, 照射野全開時, 照射野 絞り時，照射野絞りと濃度補償用フィル夕を使用した ときの線量分布を測定した。な挹，透視による 1 分 間当たりの線量を測定し, 透視条件は装置の自動露 出機構を作動させ管電圧 $50 \sim 52 \mathrm{kV}$, 管電流 $50 \mathrm{~mA}$, パルス幅 $2 \mathrm{msec}$ ，パルスレート $15 \mathrm{p} / \mathrm{s} の$ 範囲で照射を 行った。

\section{1-4 防護具による術者手指被曝低減効果}

\section{1-4-1 天井懸垂型防護板}

臨床で用いられている天井懸垂型防護板が術者手 指線量に及ぼす影響について，基礎的および臨床的 な効果を調べた。

人体ファントムを用いた基礎的検討では, 臨床で 用いられる正面, RAO30度, LAO60度, cranial25
度, caudal25度の各方向について, Fig. 1(b)に示すよ うにファントムに防護板を密着させた状態より上方へ $1 \mathrm{~cm}$ 間隔で移動し，防護板後方位置での空間線量に ついて，電離箱式サーベイメータの測定位置を固定 し線量測定を行った。実験には装置(1)を用い，透視 による 1 分間当たりの線量を測定し，透視条件は装 置の自動露出機構を作動させ管電圧 $70 \sim 79 \mathrm{kV}$, 管電 流4.2〜4.5mA，パルス幅4.5〜 4.6msec，パルスレート $15 \mathrm{p} / \mathrm{s}$ の範囲で照射を行った。

臨床における防護板の影響を調べるため, 心臓領 域での手技時の面積線量值に有意差を認めない症例 において，術者自身の判断により防護板を使用した 40症例群と防護板を使用しない40症例群について, TLDにて測定した 1 症例当たりの術者左右手背(第 2 指側および第 5 指側) と指部(第 2 指および第 5 指)で の計 8 力所の最大 $\mathrm{H} 70 \mu \mathrm{m}$ について両群の有意差検定 を $\mathrm{t}$ 検定にて比較した。

\section{1-4-2 防護手袋}

防護手袋による術者の手指線量の低減効果を検討 するため，防護手袋のX線遮蔽効果の測定および臨 床使用時の効果について調べた。

防護手袋による直接X線(照射野内において被写体 を透過しないX線) と散乱X線の遮蔽率をFig. 1(c)の 配置で測定した。測定は管電圧 $50 \mathrm{kV}$ から $120 \mathrm{kV}$ の範 囲にて, 直接X線は照射野内, 散乱X線は照射野外の 散乱線比率(散乱X線量 / 直接X線量) が10 15\% 程 度の位置とし, 防護手袋未使用時と防護手袋内一電 離箱線量計を挿入したときの線量について装置(2)を 
用いて測定した。遮蔽率 (Shielding Effect Rate)は次 式にて算出した.

Shielding Effect Rate $(\%)=\left(\left(\mathrm{D}_{0}-\mathrm{D}\right) / \mathrm{D}_{0}\right) \times 100 \cdots(1)$ このとき

$\mathrm{D}_{0}$ : 防護手袋未使用時線量

$\mathrm{D}$ ：防護手袋使用時線量

である。また，各管電圧はアルミニウム減弱法による 半価層測定より実効エネルギーを算出した。

臨床において，術者が防護手袋を使用したときの 効果を調べるため, 術者の判断により通常の手袋を 使用して手技を行った群と防護手袋を使用した群に ついて，1-2-2 で手指線量の高かった四肢領域の VAIVT時で比較した。両群各30症例は，透視時間に 有意差を認めない症例を選択し，TLDにて測定した 1 症例当たりの術者左右手背と指部の 8 力所での最大 $\mathrm{H} 70 \mu \mathrm{m}$ について両群の有意差検定を $\mathrm{t}$ 検定にて比較 した。なお，VAIVTの手技を行った装置には，面積 線量計が装備されていないため透視時間で症例の選 択を行った。

\section{1-5 術者の被曝低減意識が手指線量へ及ぼす影響}

術者の手指被曝の低減意識による線量の比較を行 うため，1-2-2 で手指線量の高かった四肢領域の VAIVTにおいて, 同一術者で手指被曝に関して全く 意識せず手技を行った群と線量低減を意識して行っ た群について比較した。なお, 術者の手指被曝低減 方法については, 照射野内への手指の挿入は必要最 小限にする，照射野近傍での手指位置の注意，被曝 低減が可能な装置の幾何学的配置の確認, 透視時間 の短縮に意識して手技を行うように説明した。対象は 両群各30症例とし，1-4-2 と同様に透視時間に有意差 を認めない症例を選択し，1 症例当たりの術者手指部 での最大 $\mathrm{H} 70 \mu \mathrm{m}$ について, 両群の有意差検定を $\mathrm{t}$ 検 定にて比較した。

\section{2. 結 果}

\section{2-1 術者の手指線量}

\section{2-1-1 術者の皮膚線量}

血管撮影領域における 1 症例ごとの術者部位別の $\mathrm{H} 70 \mu \mathrm{m}(\mathrm{mSv})$ をFig. 2に示す。各部位の線量 $[$ mean士 standard deviation (以下, SD)]は, 頸部0.14 $\pm 0.15 \mathrm{mSv}$, 左肩 $0.24 \pm 0.34 \mathrm{mSv}$, 右肩 $0.06 \pm 0.04 \mathrm{mSv}$, 左手 $0.46 \pm$ $0.37 \mathrm{mSv}$, 右手 $0.32 \pm 0.30 \mathrm{mSv}$, 左指 $0.58 \pm 0.53 \mathrm{mSv}$, 右指0.76士0.75mSvとなった。部位別に大きなバラッ キが存在し手指部の線量が高く, 右指部が最も高い 結果となった。

\section{2-1-2 検査領域別の術者手指線量}

検査領域別での 1 症例ごとの術者手指部の $\mathrm{H} 70 \mu \mathrm{m}$

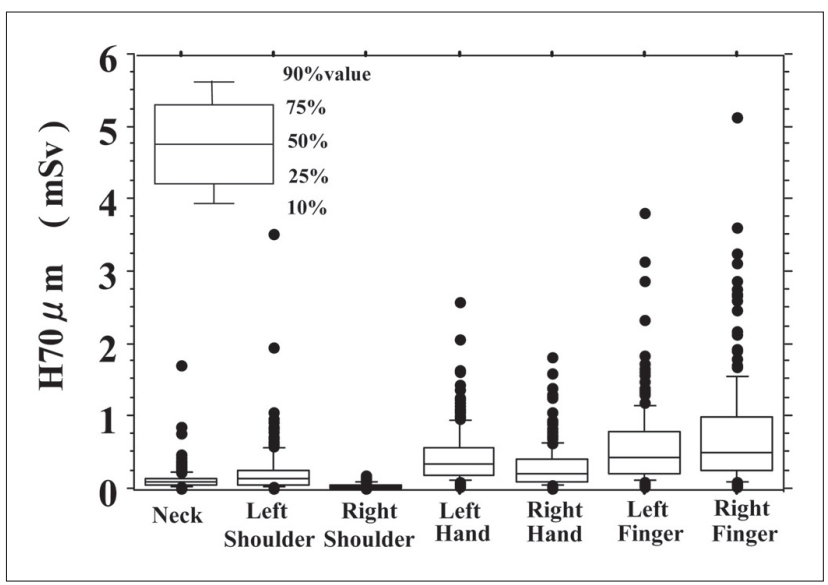

Fig. 2 Distributions of operator's average skin equivalent dose $(70 \mu \mathrm{m})$ in interventional radiology (IVR) and angiography.

Measuring points of the skin equivalent dose are neck, left and right shoulders, 2nd and 5th finger side of the back of both hands, and 2nd and 5th fingers. Higher doses between the 2nd and 5th sides were adopted for the hands and fingers of the exposure dose. The lower and upper bars show $10 \%$ and $90 \%$ doses, and the lower and upper borders of the boxes show the $25 \%$ and $75 \%$ doses, respectively, and the bars in the boxes show median doses.

（mSv）をFig. 3に示す.Fig. 3(a)は頭部領域，（b）は心 臓領域，（c）は腹部領域，（d）は四肢領域である。手指 部の線量が比較的高い領域は四肢領域であり, 右指線 量 $($ mean $\pm \mathrm{SD})$ は0.94 $\pm 0.76 \mathrm{mSv}$, 左指は0.69 $\pm 0.64 \mathrm{mSv}$ となった。

\section{2-1-3 穿刺部位別の術者手指線量}

心臓領域における穿刺部位の違いによる 1 症例ご との術者手指部の $\mathrm{H} 70 \mu \mathrm{m}(\mathrm{mSv})$ をFig. 4に示す. Fig. 4(a)の右大腿部穿刺症例と (b) の右橈骨部穿刺症例で の各手指部における平均線量は，右橈骨部穿刺症例 が若干高值であったが，標準偏差は右大腿部穿刺症 例で大きく，1 症例当たり $2 \mathrm{mSv}$ を超える症例が多く 存在した.

また，両群での 1 症例ごとの総面積線量を $\mathrm{t}$ 検定 にて比較した結果をFig. 4(c)に示す。右大腿部穿刺 症例の平均值は $83.9 \mathrm{~Gy} \cdot \mathrm{cm}^{2}$, 右橈骨部穿刺症例の平 均值は $49.4 \mathrm{~Gy} \cdot \mathrm{cm}^{2}$ となり, $\mathrm{P}=0.03$ と両群は有意に差が ある結果となった。

\section{2-2 X線装置に関連する術者手指被曝への影響}

\section{2-2-1 幾何学的配置による影響}

血管撮影領域において用いられるアンダーテーブ ル方式にて検出器と被写体の間に手技スペースを確 保するためには，Fig. 5に示すようにFSDを短くする 方法とFIDを長くする方法がある. 

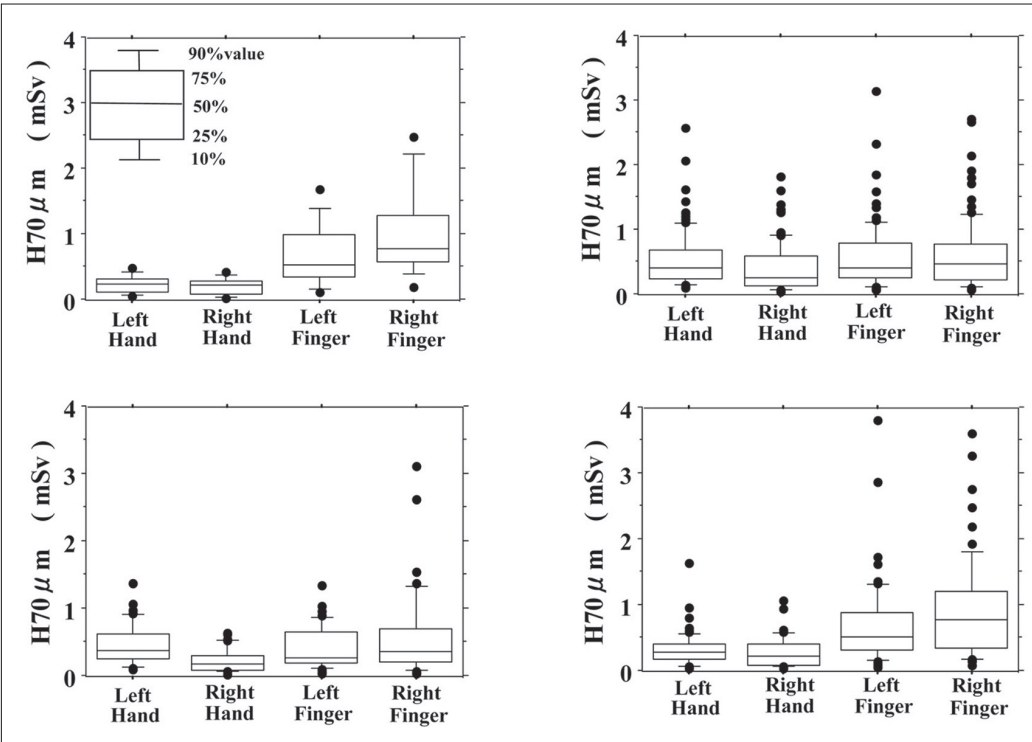

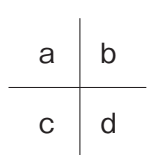

Fig. 3 Distributions of average $70 \mu \mathrm{m}$ for both operator's hands and fingers in each examination region.
(a) Neurological region.
(b) Cardiac region.
(c) Abdominal region.
(d) Extremity region.

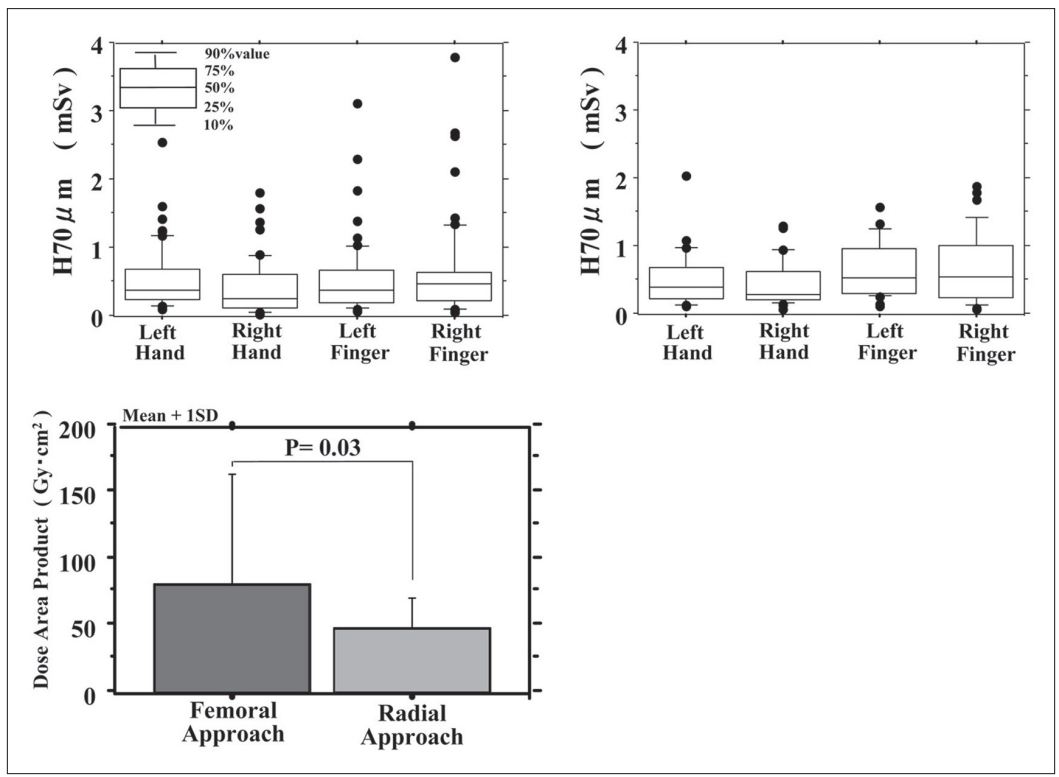

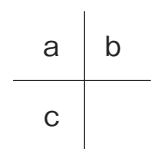

Fig. 4 Distributions of average $70 \mu \mathrm{m}$ for both operator's hands and fingers in the approach to the cardiac region.

(a) Femoral approach.

(b) Radial approach.

(c) Comparison of the dose area product value at the femoral and radial approaches.
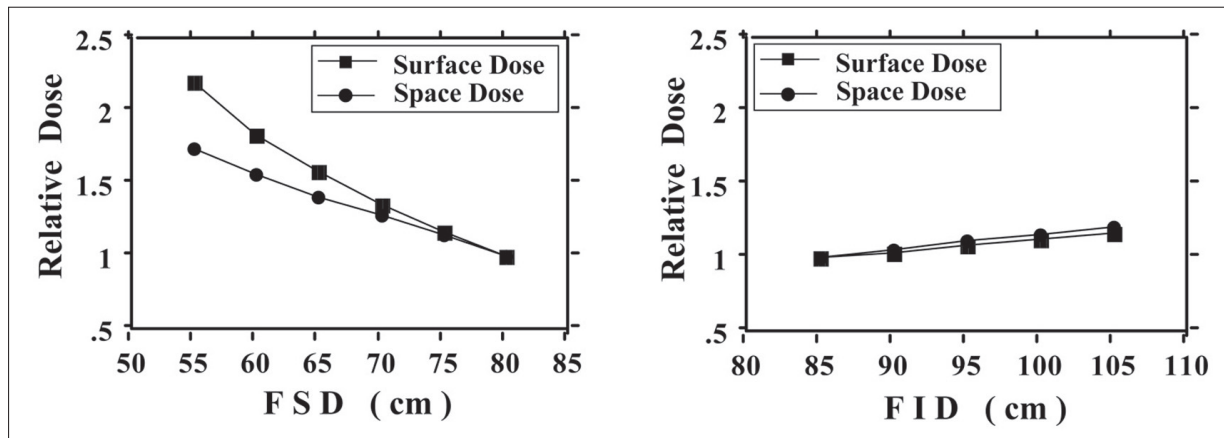

Fig. 5 Relative space dose and entrance dose of the phantom surface according to the FSD or FID value.

(a) Relative space dose and surface dose at each FSD (space $a \mid b$ dose/space dose at FSD $80 \mathrm{~cm}$, entrance phantom surface dose/entrance phantom surface dose at FSD $80 \mathrm{~cm}$ ).

(b) Relative space dose and surface dose at each FID (space dose/space dose at FID $85 \mathrm{~cm}$, entrance phantom surface dose/entrance phantom surface dose at FID $85 \mathrm{~cm}$ ). 


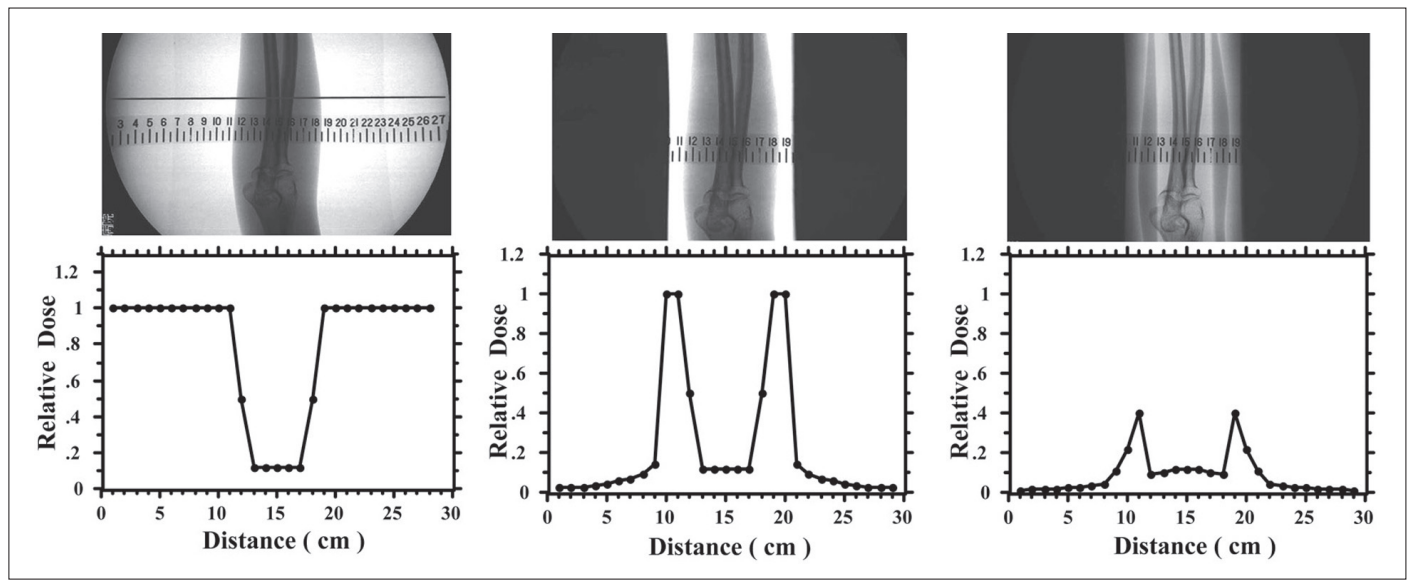

$a|b| c$

Fig. 6 Dose distribution with the under-table system according to radiation field size.

The relative dose to direct radiation for a $1 \mathrm{~cm}$ interval point within the lines in the photograph (a) .

(a) Dose distribution in the fully opened radiation field.

(b) Dose distribution in the radiation field made by diaphragm.

(c) Dose distribution in the radiation field made by diaphragm and compensating filter.

Fig. 5(a)はFIDを $100 \mathrm{~cm}$ 一定とし，FSDを $80 〜 55 \mathrm{~cm}$ (スペース間隔 0 25cm) と変化させ, FSDが $80 \mathrm{~cm}$ の空間線量と入射表面線量に対する相対線量を示 す。空間線量はスペース間隔が大きくなる (FSDが短 くなる)に従い相対線量は高くなり，スペース間隔 0 一 $25 \mathrm{~cm}$ において相対線量は $1.00 〜 1.740$ 範囲となった。 また，入射表面線量も同様な傾向を示し，相対線量 は1.00〜2.20の範囲となった。

Fig. 5(b)はFSDを 65cm一定とし，FIDを 85〜 105cm (スペース間隔 $0 \sim 20 \mathrm{~cm}$ ) と変化させ，FIDが $85 \mathrm{~cm}$ で の空間線量と入射表面線量に対する相対線量を示 す。空間線量はスペース間隔が大きくなる(FIDが長 くなる)に従い相対線量は高くなり，スペース間隔 0 一 $20 \mathrm{~cm}$ において相対線量は $1.00 〜 1.210$ 範囲となった. また，入射表面線量も同様な傾向を示し，相対線量 は1.00〜1.17の範囲となった。

Fig. 5より，手技スペースを確保するためにはI.I.を 上げる方法が，テーブルを下げる方法に比較して空 間線量比と入射表面線量比が低い結果となった。

\section{2-2-2＼cjkstart照射野による影響}

照射野の変化による照射野内線量への影響を評価 するため，照射野全開時，照射野絞り時，照射野絞 りと濃度補償用フィルタを使用したときの画像と Fig. 6(a)のライン部分での直接X線量に対する相対線量 分布の結果を示す.

Fig. 6(a) と比較しFig. 6(b)では直接X線の入射範囲 が狭くなり，照射野絞りの部分での線量は大幅に低 下し，Fig. 6(c) の照射野絞りと濃度補償用フィルタを 併用することにより，直接X線の入射がなくなり照射 野内全体の線量分布が低下した。なお, 照射野絞り 部分では直接X線の約 1\%程度に減少した。

\section{2-3 防護具による術者手指被曝低減効果}

\section{2-3-1 天井懸垂型防護板}

被写体に防護板を密着させた状態より上方へ $1 \mathrm{~cm}$ 間隔で移動し，防護板後方位置での空間線量につい て，各角度における防護板を使用しない線量に対す る相対線量の結果をFig. 7(a)に示す. 防護板を密着 させた状態より $3 \mathrm{~cm}$ 上方までの間隔において，防護 板による空間線量低減効果が認められた.

臨床における防護板の効果をFig. 7(b)に示す。心 臓領域IVRにおける 1 症例当たりの手指部での最大 $\mathrm{H} 70 \mu \mathrm{m}($ mean $\pm \mathrm{SD})$ は，防護板を使用しない群におい て1.04 $00.64 \mathrm{mSv}$ ，防護板を使用した群において $0.76 \pm 0.44 \mathrm{mSv}$ となり, 2 群の比較では $\mathrm{p}=0.02$ と有意 差が認められ，防護板を使用し手技を行うことにより 手指部での線量が低減される結果となった。なお, 同一症例における 2 群の面積線量值の比較におい て, Fig. $7(\mathrm{c})$ より $\mathrm{p}=0.93$ と手技時の面積線量值は有意 差を認めない.

\section{2-3-2 防護手袋}

防護手袋による線量低減効果について, Fig. 8(a) に直接X線部分と散乱X線部分における装置実効エネ ルギーと遮蔽率の関係を示す。直接X線部分では実 効エネルギー26.5〜38.5keVにおいて遮蔽率は67〜 $36 \%$, 散乱X線部分では遮蔽率は73４2\%となり，実 効エネルギーが高くなるに従い防護手袋による線量 低減効果が低くなる結果となった。 なお, 装置の管 電圧50，70，100，120kVにおける実効エネルギーは それぞれ26.5, 30.0, 35.5, 38.5 keVである。

防護手袋による臨床での効果をFig. 8(b)に示す. VAIVTにおける 1 症例当たりの手指部での最大 $\mathrm{H} 70 \mu \mathrm{m}($ mean $\pm \mathrm{SD})$ は，通常の手袋を使用した群にお 

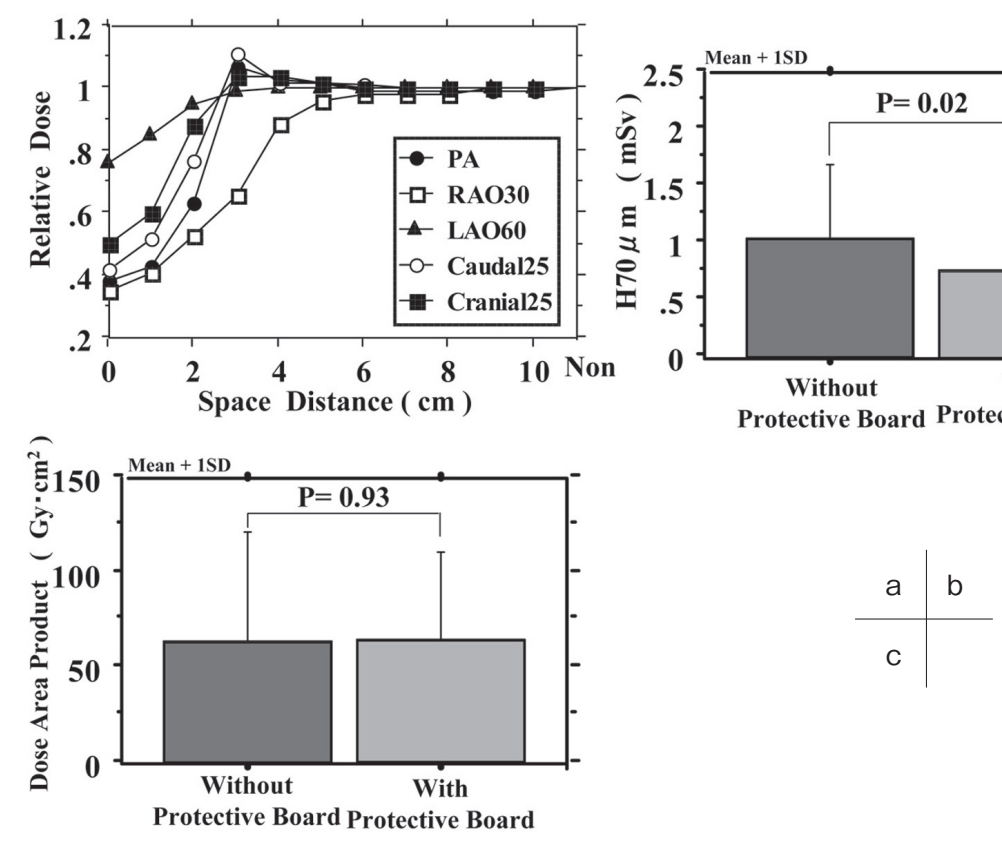

Fig. 7 Shielding effect of the protective board.

(a) Relative space dose at the height of the protective board from the phantom for each C-arm angle.

(b) Comparison of $70 \mu \mathrm{m}$ for the operator's hands and fingers with and without protective board.

(c) Comparison of the dose area product with the same cases as (b).

Fig. 8 Shielding effect of the protective glove.

(a) Relationship between the effective energy and the shielding effect rate of the protective gloves for direct and scatter radiation.

(b) Comparison of $70 \mu \mathrm{m}$ for the operator's hands and fingers between the normal glove and the protective glove.

(c) Comparison of the fluorotime with the same cases as (b).

いて $1.08 \pm 0.69 \mathrm{mSv}$, 防護手袋を使用した群において $0.60 \pm 0.40 \mathrm{mSv}$ となり, 2 群の比較では $\mathrm{p}=0.003$ と有意 差が認められ，防護手袋を使用し手技を行うことによ り手指部での線量が低減される結果となった。な お, 同一症例における 2 群の透視時間の比較におい て, Fig. 8(c)より p=0.42と有意差を認めない.

\section{2-4 術者の被曝低減意識が手指線量へ及ぼす影響} 術者の被曝低減意識が手指線量に及ぼす影響を調 ベるため, 同一術者で手指被曝に関して全く意識せ
ず手技を行っていた群と線量低減を意識して行った 群について，1 症例当たりの手指部での最大 $\mathrm{H} 70 \mu \mathrm{m}$ (mean \pm SD)の比較を行った結果をFig. 9に示す.

Fig. 9(a)より，意識せず手技を行った群は $1.52 \pm$ $0.84 \mathrm{mSv}$ ，意識して手技を行った群は0.98 $00.77 \mathrm{mSv}$ となり, 2 群の比較では $\mathrm{p}=0.04$ と有意差が認められ， 術者が被曝低減を意識して手技を行った場合には, 手指部での線量が低減される結果となった。なお, 同一症例における 2 群の透視時間の比較において, Fig. 9(b)より $\mathrm{p}=0.68$ と有意差を認めない. 


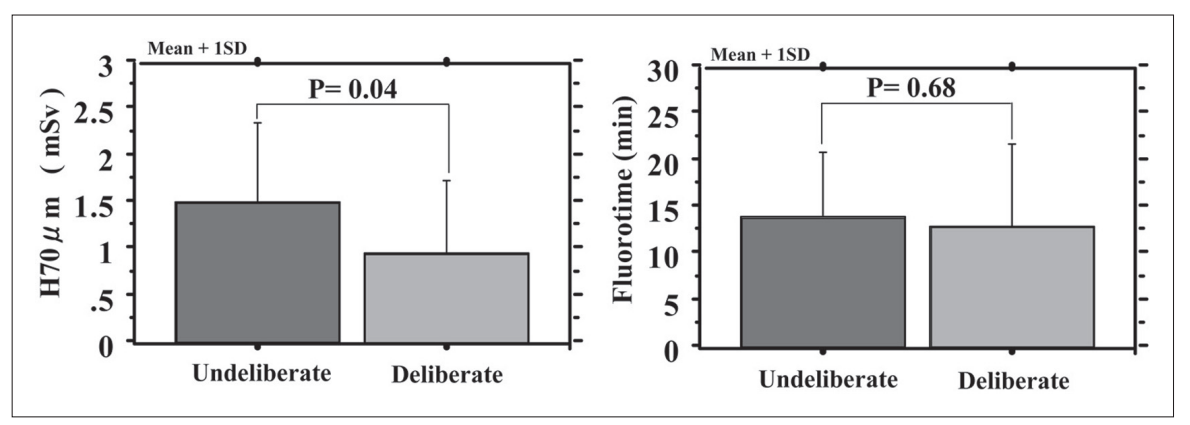

$a \mid b$

Fig. 9 Changes in the exposed dose to the operator's hands and fingers with their deliberation to exposure dose reduction.

(a) Comparison of $70 \mu \mathrm{m}$ for the operator's hands and fingers.

(b) Comparison of the fluorotime with the same cases as (a).

\section{3. 考 察}

IVRは急速に進歩発展している臨床専門分野であ り, 症例数の増加や手技の高度化が進んでいる。特 に術者は高い専門性が要求されることから，特定の 術者が多くの手技を行う傾向にある，術者の被曝部 位はFig. 2より手指部で高い線量を示すが, 体幹部, 甲状腺や眼の水晶体などの部位に比べ防護衣や防護 具による被曝線量低減措置が確立していない。そこ で本研究では, 血管撮影領域での臨床における術者 手指線量低減方法について検討した。

\section{3-1 術者の手指線量}

血管撮影領域における術者皮膚のH70 $\mathrm{mm}(\mathrm{mSv})$ を 評価した結果(Fig. 2), 各部位で 1 症例ごとに大きな バラツキが存在し, 手指線量が他の部位に比較し高 值を示した。血管撮影領域における術者の被曝は, 多くの部位で散乱X線により影響を受けるが, 手指部 では直接X線による影響を受ける場合がある。このた め, 他の部位に比較し被曝線量の分布範囲が広く, 高い線量が存在したと考えられる。手指部のなかで 線量が高い右指は, 多くの術者の利き腕側となるた め穿刺時や細かい操作時に透視照射野内に接近し線 量が高くなり，第 2 指と第 5 指側を比較すると第 2 指側の線量が高くなる傾向であった。 また，左手部 の線量が右手部に比較し高い原因は, 穿刺部のシー ス等を手技中に固定することが多く，常に照射野側 に近い位置関係となるため透視時の散乱X線の影響 を大きく受けるためと考えられる。なお，第 2 指と第 5 指側を比較すると第 5 指側の線量が高くなる傾向 であった。このように，手指部は臨床において照射野 内入入る可能性があり直接X線による影響を受け，ま た手技中に照射野近傍に位置することより線量が高 值になると考えられる。そこで，検査領域と穿刺部位 の違いが術者手指線量に及ぼす影響について検討し た.

検査領域別での術者手指線量について評価した結 果, Fig. 3より 1 検査ごとの線量が高い領域は四肢領
域のVAIVTであった. VAIVTは，他の手技と異なり 穿刺部位と治療部位が極めて近いため術者手指は常 に照射部位の近傍に位置し，手技上の必要に応じて 手指が照射野内に入る可能性があることなどから手 指線量が高くなったと考えられる。また，VAIVTは 他の検査領域に比較し大幅に患者入射皮膚線量が少 ないことから ${ }^{12,17)}$, 検査時の総X線量に対する術者 手指線量の比率が高い手技である.

穿刺部位による術者手指線量に及ぼす影響を評価 するため心臓領域で検討した，Fig. 4より各手指部に おける平均線量はほぼ同じであったが，橈骨部穿刺 症例による手指部の線量が若干高かった。橈骨部穿 刺により手指線量が高くなる原因として, 穿刺時やカ テーテル操作時に被写体外側からの直接X線(Fig. 6 (b)での照射野端と被写体の間の高い線量)の影響を 受ける頻度が多いためと考えられる。また，大腿部 穿刺症例は標準偏差が大きく平均值より大幅に高い 線量が存在した。これは，橈骨部に比べ大腿部では 被写体厚が厚いため透視条件が高く, 穿刺時に高い 線量率の直接X線による影響を受けたためと考えられ る.なお, Fig. 4(c)より右大腿部穿刺症例(平均值 $83.9 \mathrm{~Gy} \cdot \mathrm{cm}^{2}$ ) が右橈骨部穿刺症例 (平均值 $49.4 \mathrm{~Gy} \cdot \mathrm{cm}^{2}$ ) に比較し有意に総面積線量值が高かった。総面積線 量值は手指線量にも相関が認められるため ${ }^{13)}$, 同程 度の総面積線量時には橈骨部穿刺による手技が手指 線量を高くすると考えられる。

\section{3-2 手指被曝低減効果}

血管撮影時の術者手指部は清潔を維持し, 手技の 妨げにならないような放射線防護が必要になるため, 眼, 頸部などの他の部位に比較し防護方法が確立し ていない. そこで, 術者手指被曝の低減方法につい てX線装置に関連する影響，放射線防護用具を用い た場合, 術者の被曝意識による変化について検討し た。

術者が透視照射野近傍で手技を行う場合, アン ダーテーブル方式では被写体と検出器との間にス 
ペースが必要となる。スペースを確保するためには,

Fig. 1(a)に示すようにテーブルを下げFSDを短くする 方法とI.I.を上げFIDを長くする方法がある. Fig. 5よ り同じ間隔のスペースを確保する場合，I.I.を上げる ことによりテーブルを下げる場合より入射表面線量の 増加率が低く, 周辺の空間線量の増加率も低い結果 となった。 これより, 手技スペースを確保する場合に はI.I.を上げるべきであり，患者位置での入射線量を 低減することにより術者手指線量も低減されると考え られる。 また，入射線量を低減する低パルスレートな どの使用は術者手指線量の低減につながると考えら れる.

術者の手指線量が高くなる最大の原因は直接 $\mathrm{X}$ 線 による被曝である。これは，透視・撮影時に照射野 内の直接X線部分に手指が入るためであり，照射野 内の線量分布が大きな影響を与える。 アンダーテー ブル方式の場合，照射野が全開のFig. 6(a)は直接X 線部分が広くX線束内へ術者手指が入った場合には 手指線量が高くなり, Fig. 6(b)のコリメータにより照 射野を絞ることで直接X線の入射範囲が狭くなり周辺 部の線量は大幅に低下し, Fig. 6(c)の照射野絞りと 濃度補償用フィルタを併用することにより, 直接X線 の入射部位がなくなり照射野内全体の線量分布が低 下した。検査部位の形状に合わせて適切に照射野を 絞り，濃度補償用フィルタなどを併用することによ り, 直接X線による手指被曝を回避することが重要で あると考える。なお，オーバーテーブル方式では常に 照射野内人入射する直接X線部分が存在し, さら に，Vañóらにより術者の水晶体障害の事例が報告5) されていることからもオーバーテーブル方式を血管撮 影で使用すべきではないと考えられる。

防護具を用いることによる術者手指被曝の低減効 果について, 天井懸垂型防護板と防護手袋で確認す ることができた。一般的に天井懸垂型防護板は術者 の上半身の防護に有效 ${ }^{18)}$ であるが，Fig. 7(a)より防護 板を被写体に密着させた状態より上方 $3 \mathrm{~cm}$ 以内で使 用することにより防護板後方での空間線量低減効果 が認められ，この位置での手指被曝は低減されると 考えられる。 また, 心臓領域IVRでの総面積線量值 に有意差を認めない防護板を使用した群と使用しな い群での比較において, Fig. 7(b)より防護板による手 指線量低減が認められ, 臨床での防護板の有効性が 示唆された。

手指の防護具 ${ }^{19)}$ として今回使用した防護手袋は, 無鉛素材であり鉛当量は公表されていないが, Fig. 8 (a)に示すような直接X線と散乱X線の遮蔽効果が確 認できた。 Fig. 3(d)の臨床において手指線量が高い VAIVT時での透視時間に有意差を認めない通常手袋
と防護手袋を着用した症例群での比較において, Fig. 8（b）に示す防護手袋を着用した群の手指線量が有意 に低い結果となったことから，臨床使用での有効性

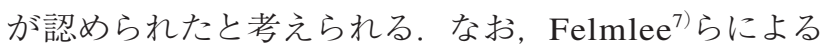
とIVRにおける術者手指線量と透視時間の関係は相 関が認められないと報告しているが，VAIVTでの両 者は強い相関が確認されている12)。また, Fig. 8(a)よ り防護手袋は手指を完全に防護するものではなく, 直 接X線部分への挿入へは注意が必要である。

術者の被曝線量低減の意識が自身の手指線量に及 ぼす影響について，透視時間に有意差を認めない 2 群を対象としたFig. 9(a)より，放射線被曝に関心がな く手技を行った群に比較し被曝線量低減を意識した 群において有意に手指線量が低い結果となった。術 者自身が手指被曝を意識することにより，透視照射 野内への手指の挿入頻度が減り，手技中の手指位置 に注意したことから手指線量が低減されたと考えら れ，さらに不要な透視を避けることによる患者被曝線 量の低減にもつながると考えられる。

以上より，血管撮影領域での術者手指被曝の現状 を評価し，術者が安全に手技を施行するための被曝 線量低減方法を検討した。術者の手指線量は他の部 位に比較し高い值となっているため, 臨床における有 効な低減方法を選択し, 術者自身にも被曝線量低減 意識を啓蒙し手技を行うことが重要になると考えられ る. 今後の課題は, 術者手指線量を手背側と手掌側 のどちらで評価するか, 手技に影響を及ぼさず被曝 低減が可能な新しい防護用具の開発，多くの術者で の手指被曝低減の意識が及ぼす影響についての検討 である。術者手指線量は他の部位に比較し高いた め, 線量低減が望まれる.

\section{4. 結 語}

血管撮影領域による術者の手指被曝線量の現状と 低減方法について検討した。手指部は他の部位に比 較し照射野近傍に位置するため線量が高く，直接X 線の影響も受ける。そこで，X線装置に関連する影響 を考慮し，放射線防護用具を用いる方法や術者の被 曝低減意識の啓蒙により線量低減が可能となった。 本研究の結果, 術者手指線量の低減方法を実行する ことにより, 術者が安全に血管撮影検査やIVRを施 行することが可能であると示唆された.

\section{謝 辞}

稿を終えるにあたり，臨床でのデータ収集に快くご 協力いただきました当院放射線科，第 2 内科循環器 グループ, 脳外科, 泌尿器科の方々に感謝の意を表 します。 


\section{参考文献}

1) Shope TB. Radiation-induced Skin Injuries from Fluoroscopy. Center for Devices and Radiological Health, FDA, 1997.

2) Koenig TR, Wolff D, Mettler FA, et al. Skin injuries from fluoroscopically guided procedures: part 1, characteristics of radiation injury. AJR Am J Roentgenol 2001; 177(1): 3-11.

3) Koenig TR, Mettler FA, Wagner LK. Skin injuries from fluoroscopically guided procedures: part 2, review of 73 cases and recommendations for minimizing dose delivered to patient. AJR Am J Roentgenol 2001; 177(1): 13-20.

4) 宋 寅傑, 石川牧子, 飯島正文。心臓カテーテルおよび 肝動脈塞栓術の施行期に生じた放射線皮膚炎. 臨床皮膚 科 $2000 ； 54$ (5 増刊)：7-10.

5) Vañó E, González L, Beneytez F, et al. Lens injuries induced by occupational exposure in non-optimized interventional radiology laboratories. Br J Radiol 1998; 71 (847) : 728-733.

6) ICRP Publication 73. Radiological Protection and Safety in Medicine. Annals of the ICRP. 1996.

7) Felmlee JP, McGough PF, Morin RL, et al. Hand dose measurements in interventional radiology. Health Phys 1991; 60(2): 265-267.

8) Kuwayama N, Takaku A, Endo S, et al. Radiation exposure in endovascular surgery of the head and neck. AJNR Am J Neuroradiol 1994; 15(10) : 1801-1808.

9）西澤かな枝，丸山隆司，高山 誠，他. 血管造影検査時 の術者グループの被曝線量. 日本医放会誌 $1994 ; 54$ (7) : 661-669.
10) Vañó E, González L, Guibelalde E, et al. Radiation exposure to medical staff in interventional and cardiac radiology. Br J Radiol 1998; 71(849) : 954-960.

11）石口恒男, 中村仁信, 岡崎正敏, 他. 肝細胞癌の動脈塞 栓療法に打ける患者と術者の被曝測定.日本医放会誌 $2000 ； 60(14): 839-844$.

12）坂本 肇，深澤瑞也，武田正之，他，BAIVTにおける術 者と患者の被曝線量. 透析会誌 $2003 ； 36(6) ： 1199-1205$.

13）坂本 肇，小林 寛，池川博昭，他．面積線量計による 術者被曝線量推定に関する検討. 日放技学誌 $2006 ; 62$ (7) : 951-960.

14) ICRP Publication 74. Conversion Coefficients for Use in Radiological Protection Against External Radiation. Annals of the ICRP. 1996.

15）濱田達二 編。第 1 部 外部被ばくマニュアル。被ばく線 量の測定・評価マニュアル，財団法人原子力安全技術セ ンター, 東京, $2000:$ 1-165

16) Seltzer SM, Hubbell JH 著, 前越 久監修. 光子減弱係 数データブック. 放射線医療技術学叢書(11). 京都：日本 放射線技術学会, 1995 .

17) Storm ES, Miller DL, Hoover LJ, et al. Radiation doses from venous access procedures. Radiology 2006; 238(3): 1044-1050

18）粟井一夫 編. 血管撮影領域に捛ける放射線被曝と防護. 放射線医療技術学叢書(17) 日本放射線技術学会, 京 都, 1999：100-105

19）斉藤 肇, 岡部圭吾, 中澤靖夫. 神経ブロック療法にお ける術者手指被曝低減の試み-Under Table方式とOver Table方式の比較一。日放技学誌 2004；60(3)：393-398.

Fig. 1 基礎的実験の幾何学的配置図

(a)スペースを確保するため, FSDとFIDを変化させファントム表面線量と空間線量を測定した.

(b) 防護板の被写体からの高さを変化させ空間線量を測定した。 (c) 直接X線と散乱X線の測定位置.

Fig. 2 血管撮影領域に扔ける 1 検査当たりの術者頸部・肩・手背・手指の皮膚 $70 \mu \mathrm{m}$ 線量当量 $(\mathrm{H} 70 \mu \mathrm{m})$ を示す。手背と手指は 2 指側 と 5 指側のどちらかの高い線量を示した。 上下の線は $10 \%$ と $90 \%$ 線量, 上下の箱は $25 \%$ と $75 \%$ 線量, 中心線は $50 \%$ 線量である.

Fig. 3 検査領域別での 1 検査当たりの術者手背・手指の皮膚 $70 \mu \mathrm{m}$ 線量当量 $(\mathrm{H} 70 \mu \mathrm{m})$ を示す.

(a)頭部領域, (b) 心臟領域, (c)腹部領域, (d)四肢領域

Fig. 4 心臓領域におけるアプローチ部位別での 1 検査当たりの術者手背・手指の皮膚 $70 \mu \mathrm{m}$ 線量当量 $(\mathrm{H} 70 \mu \mathrm{m})$ を示す (a) 大腿部アプローチ, (b) 橈骨部アプローチ, (c)大腿部と橈骨部アプローチ時での面積線量值の比較

Fig. 5 FSDまたはFIDの変化における空間線量とファントム表面での入射線量の相対值

(a) FSDが $80 \mathrm{~cm}$ での空間線量と入射表面線量に対する各空間線量と入射表面線量の相対值(空間線量/FSD $80 \mathrm{~cm}$ での空間 線量, 入射表面線量/FSD $80 \mathrm{~cm}$ での入射表面線量)

(b) FIDが $85 \mathrm{~cm}$ での空間線量と入射表面線量に対する各空間線量と入射表面線量の相対值(空間線量/FID $85 \mathrm{~cm}$ での空間線 量, 入射表面線量/FID $85 \mathrm{~cm}$ での入射表面線量)

Fig. 6 アンダーテーブル方式での照射野の変化による線量分布.

写真(a)のライン内での $1 \mathrm{~cm}$ 間隔の直接X線部分に対する相対線量で示す.

(a)照射野全開での照射野内の線量分布，（b)照射野絞りによる照射野内の線量分布

(c)照射野絞りと濃度補償用フィル夕による照射野内の線量分布

Fig. 7 防護板による遮蔽効果

(a)各Cアーム角度での防護板の被写体からの高さと空間線量の相対值

(b) 防護板使用時と未使用時での術者手指線量の比較, (c) (b) 症例での面積線量值の比較

Fig. 8 防護手袋による遮蔽効果

(a) 実効エネルギーの変化に対する防護手袋の直接X線と散乱X線の遮蔽率

(b) 防護手袋と通常手袋での術者手指線量の比較, (c) (b)症例での透視時間の比較

Fig. 9 術者の被曝意識による術者手指線量の変化

(a) 術者手指線量の比較, (b) (a) 症例での透視時間の比較 